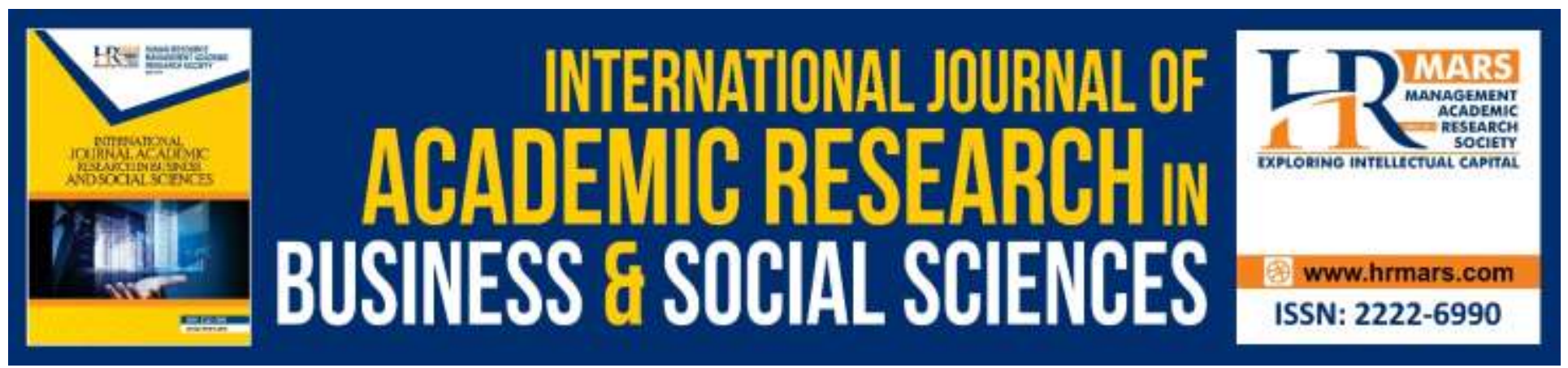

\title{
Defense Expenditures of Selected Countries in Southeast Asia
}

Amirudin Sulaiman, Mohd Nor Yahaya, Ananthan, S., Norlaila Mazura Hj. Mohaiyadin, Herlin Anak Aman

To Link this Article: http://dx.doi.org/10.6007/IJARBSS/v9-i6/6061

DOI: $10.6007 /$ IJARBSS/v9-i6/6061

Received: 01 April 2018, Revised: 29 May 2019, Accepted: 07 June 2019

Published Online: 24 June 2019

In-Text Citation: (Sulaiman, Yahaya, Ananthan, Mohaiyadin, \& Aman, 2019)

To Cite this Article: Sulaiman, A., Yahaya, M. N., Ananthan, S., Mohaiyadin, N. M. H., \& Aman, H. A. (2019). Defense Expenditures of Selected Countries in Southeast Asia. International Journal of Academic Research in Business and Social Sciences, 9(6), 1002-1015.

Copyright: (C) 2019 The Author(s)

Published by Human Resource Management Academic Research Society (www.hrmars.com)

This article is published under the Creative Commons Attribution (CC BY 4.0) license. Anyone may reproduce, distribute, translate and create derivative works of this article (for both commercial and non-commercial purposes), subject to full attribution to the original publication and authors. The full terms of this license may be seen

at: http://creativecommons.org/licences/by/4.0/legalcode

Vol. 9, No. 6, 2019, Pg. 1002 - 1015

http://hrmars.com/index.php/pages/detail/IJARBSS

JOURNAL HOMEPAGE

Full Terms \& Conditions of access and use can be found at http://hrmars.com/index.php/pages/detail/publication-ethics 


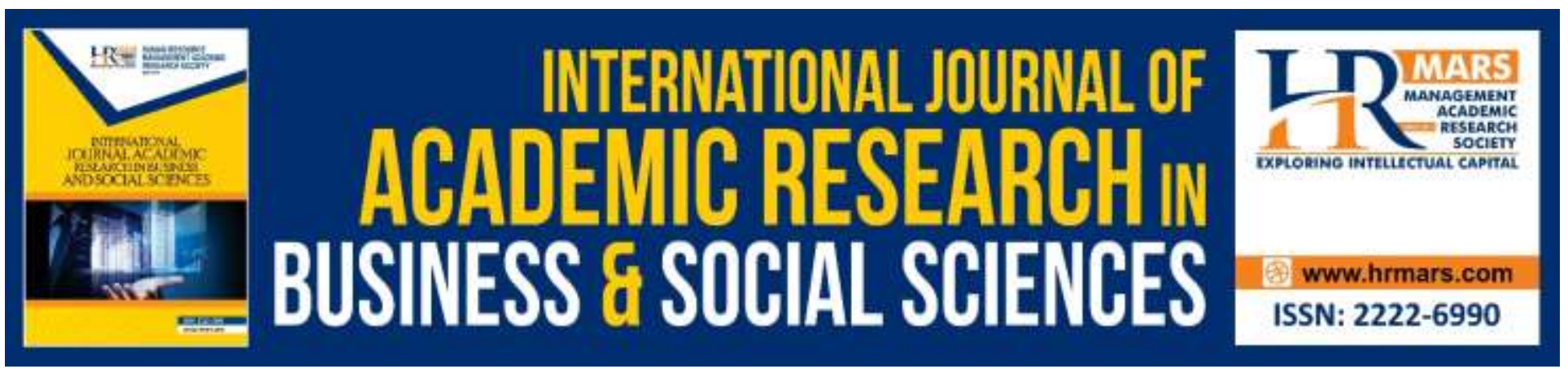

\title{
Defense Expenditures of Selected Countries in Southeast Asia
}

\author{
Amirudin Sulaiman, Mohd Nor Yahaya, Ananthan, S., Norlaila \\ Mazura Hj. Mohaiyadin, Herlin Anak Aman \\ National Defense University of Malaysia, Malaysia
}

\begin{abstract}
Most if not all countries in Southeast Asia have continued to increase their defence expenditures since the end of the Cold War. However, the literature in this area is still lacking and another similar study merely focuses on countries in the Middle East and the Far East. This study aims: (1) To analyse the trends in defence expenditures of selected countries in Southeast Asia, namely Indonesia, the Philippines, Malaysia, Singapore and Thailand and (2) To identify other factors that may affect their defence expenditures. This study applies a qualitative research method called content analysis from the Military Balance online database by compiling defence expenditures data in selected countries in Southeast Asia from 1988 to 2007 for the first aim and reviews existing literatures on factors that may affect their defence expenditures for the second aim of this study. Results show that there is a decreasing trend for defence expenditures as a percentage of GDP and an increasing trend of the actual amount of defence expenditures. This study also indicates that there are other factors that may affect their defence expenditures: military technological advancements; quality, prestige and force-multipliers and arms race or maintaining the status quo. The contribution of the study is to verify evidences that these selected Southeast Asia countries need to develop their own defence for their national sovereignty and integrity to replace old and antiquated military equipment, as well as attaining prestige and force-multipliers effects to achieve a form of national status and enhancing the military capabilities of their armed forces.
\end{abstract}

Keywords: Trend In Defence Expenditures, Southeast Asia, Military Technological Advancements, Quality, Prestige, Force-Multipliers, Arms Race

\section{Introduction}

Defense expenditure is the amount of 'expenditures' that are essential resources devoted to defense from the public expenditure budget of the country (Whynes, 1979). Defense expenditure is defined as "the commitment or organization of financial resources for the purpose of preserving and enhancing a country's security from military threats either physical (real) or psychological (in the realm of perceptions), internal or external" (Chin, 1987). Defense expenditure also relates to the 
procurement or acquisition of military equipment, such as aircraft, ship, missile, armored and other land vehicles, etc. (IISS The Military Balance 2005).

The provision for defense expenditure of a country is an 'opportunity cost' to the country, which means that once the resources for defense are spent, it can no longer be made available to acquire other resources or be made available for the production of other products or services (MIDMC, 2007). In other words, with more provision for defense expenditure, it will forgo more provision for public transport, health care, school, road, dam, rice, corn, potato or wheat, with the assumptions that all other things remain unchanged, constant, or otherwise termed as ceteris paribus; and it works both ways. The more spent on the latter implies that less is spent on the former. It is a matter of choice in allocating the scarce resources. Defense expenditure is not free: similar to other expenditures, it involves the sacrifices of other goods and services, raising questions (Hartley and Sandler, 1990). An example would be a developing country that gives priority towards socio-economic development provision rather than defense provision in the annual budget that provides a larger portion towards socio-economic development and a smaller portion given to defense. However, this is only a simple example and the real world can give a different picture altogether.

The distinction between a developed, developing or less developing country can be observed through the value of per capita national income or Gross National Product and all other related factors, such as the standard of living, the provision of basic amenities, the level of education or literacy and etc. (Whynes, 1979). Developed countries are those countries located in the West and in Asia, such as Japan, whereas the less developed countries are those countries, such as Africa and developing countries are those in between the developed and less developed countries, such as Malaysia, Indonesia and Thailand. This distinction is necessary so that comparisons can easily made between these countries later in this study.

The term 'military' or 'defense' can be somewhat ambiguous. In some countries, it may include the police forces, or the militia (Whynes, 1979). However, for the purpose of this study, 'military' or 'defense' refers as a country's standing army, navy and air force. Additionally, it will also include security force and the defense administration, where it was provides by the national budget. The governments of the Southeast Asia countries can generally divided into two; democracy, which is constitutionally subservient or represented by a civil government, and to which a proportion of public funds is devoted and military regime, which arises from coup, seizure of power, and the leader of its armed forces controls the state.

From the data provided by the Stockholm International Peace Research Institute (SIPRI), there is a general trend of increasing defense expenditures since the late 1980s to 2007 for countries around the world. This pattern of trend in defense expenditure is similar for Southeast Asia countries. However, from 1997 and onwards, there was a declining trend, which started to pick-up again in 2001 as shown in Fig. 1. Fig. 2 shows that the highest defense expenditure led by Singapore and followed by Indonesia, Malaysia, Thailand and Philippines respectively, and these countries continue to have large yearly defense expenditures. In 1988, the total defense expenditures for these 5 countries were just about USD8 billion, but it has grown to over USD17 billion in 2007, more than double in the last 20 years. In other words, generally, the regional trend reflects similar increases of defense expenditures to that of other countries and regions of the world. 
Most of the countries in the Southeast Asia region are developing countries and as developing countries, where the apportionment of the national income for security or defense should be appropriate with the priority given to socio-economic development, assuming, of course, the absence of any internal and external threats. However, in the real world, it is not as easy as that; Chin stated that: “...defense expenditures or defense spending by any country is primarily to finance its standing army or armed forces against those who may intend to challenge the sovereignty and the integrity of another nation" (Chin, 1987). Chin also stated that: "There is an all-too-ready assumption that at the national level, the basic spending on defense is most obviously worked out in a context of perceived or actual threats to the state, but defense spending at that level is also about allocation of scarce or limited national resources" (Chin, 1987). In simple terms, defense expenditure by any developing country can affect other portions of its national income and it is about making choices on how best to spend so that there is a 'balance' between socio-economic development and defense. This 'balance' is prioritizing a major chunk of the national income towards developing the country and a portion allotted for defense to ensure that the sovereignty and integrity of the country remain intact. Thus, this study attempts to analyses the trends in defense expenditures of these selected countries in Southeast Asia and to identify other factors that may affect their defense expenditures in the Southeast Asia region, despite the relative peace attained since after the end of the Cold War that have increased their respective defense expenditures. This study applies a qualitative research method called content analysis from the Military Balance online database by compiling defense expenditures data in selected countries in Southeast Asia from 1988 to 2007 and reviews the existing literatures on factors that may affect the increasing trend of defense expenditures for selected Southeast Asia countries.

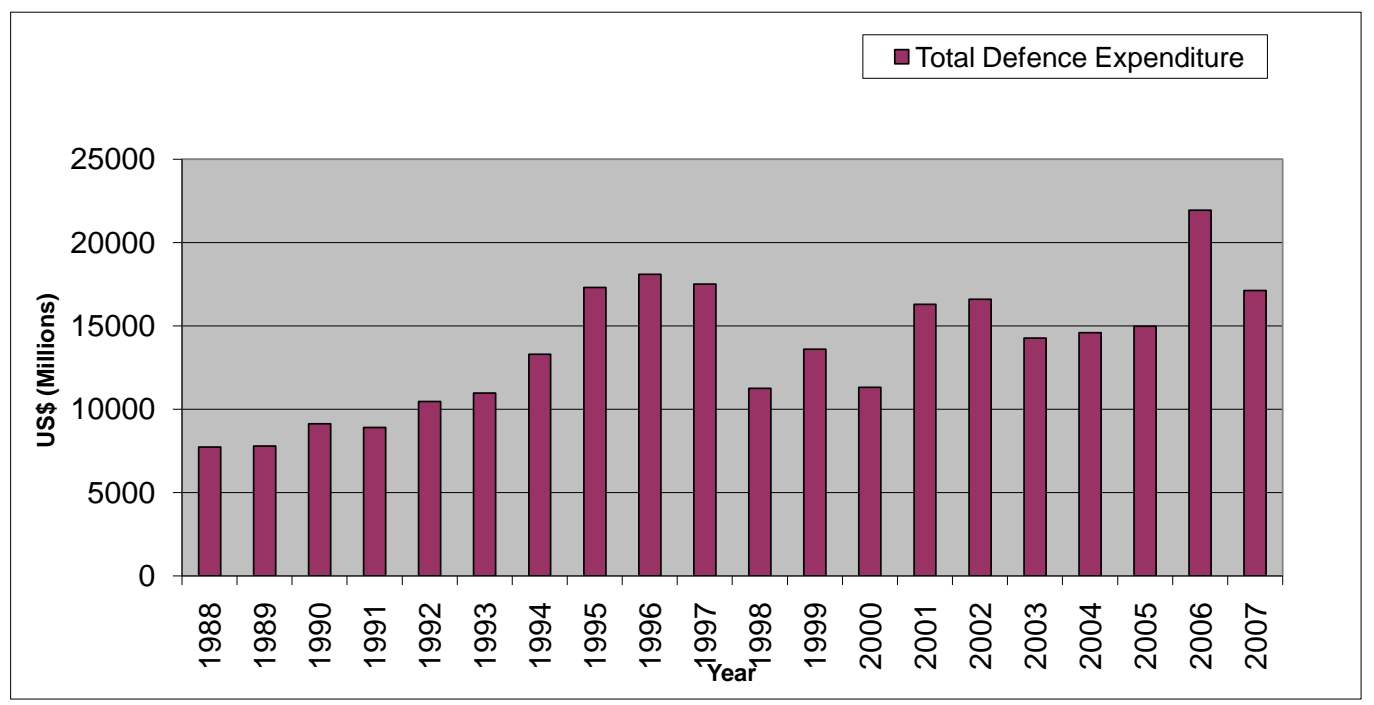

Data Source: IISS's The Military Balance 1990/1991 to 2009 issues.

Fig. 1: Yearly Total Defense Expenditures for Selected Countries in Southeast Asia 


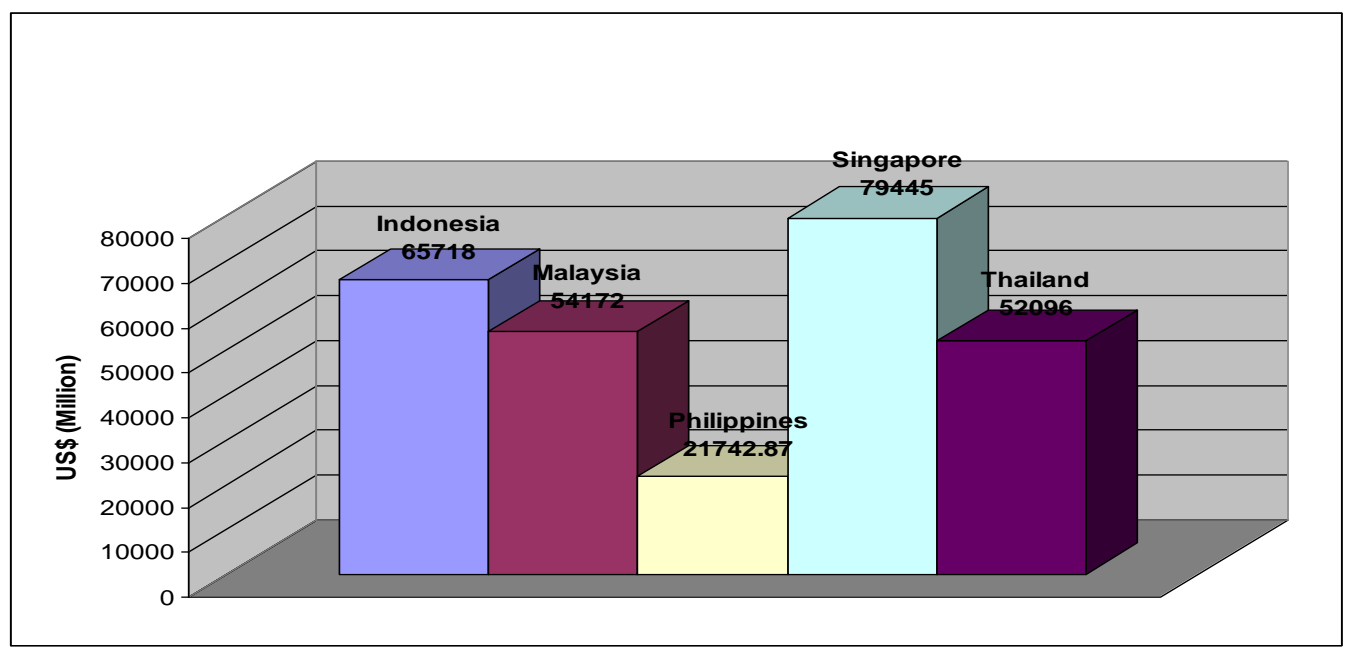

Data Source: IISS's The Military Balance 1990/1991 to 2009 issues.

Fig. 2: Total Defense Expenditures from 1988 to 2007 for Selected Countries in Southeast Asia Trends for Defense Expenditures

\section{Decreasing Trend for Defense Expenditures as a Percentage of GDP}

TABLE I shows a summary of defense expenditure as a percentage of GDP. Generally, the defense expenditure as a percentage of GDP for selected countries, such as Indonesia, Malaysia, the Philippines, Singapore and Thailand indicates a decreasing trend. There is an opportunity cost concept for each of the country's defense expenditures. Data reveals that the respective government is more concerned with socio-economic development to improve the livelihood of its citizens and thus, this area given a higher priority than defense. However, it does not mean that they totally neglect the defense and security requirements. Despite the decreasing trend, countries in the region have been able to modernize their respective armed forces by acquiring capabilities that have not seen two decades ago. The data and figures also revealed that selected countries are not only replacing their old and outdated military equipment, but also at the same time, acquiring new capabilities. Thus, the capabilities acquired for modernizing their armed forces show that the countries in the region are not only maintaining the status quo, but also transforming their armed forces to become a modern conventional force that is capable of assuring their countries' sovereignty and integrity.

TABLE I: A Summary of Defense Expenditures as a Percentage of GDP

\begin{tabular}{lll}
\hline \hline Serial & Countries & Defense Expenditures as a Percentage of the Country's GDP \\
\hline a. & Indonesia & Decreasing \\
b. & Malaysia & Decreasing \\
c. & Philippines & Decreasing \\
d. & Singapore & Decreasing \\
e. & Thailand & Decreasing \\
f. & Overall for the five & Decreasing \\
& countries & \\
\hline \hline
\end{tabular}


INTERNATIONAL JOURNAL OF ACADEMIC RESEARCH IN BUSINESS AND SOCIAL SCIENCES Vol. 9, No. 6, June, 2019, E-ISSN: 2222-6990 @ 2019 HRMARS

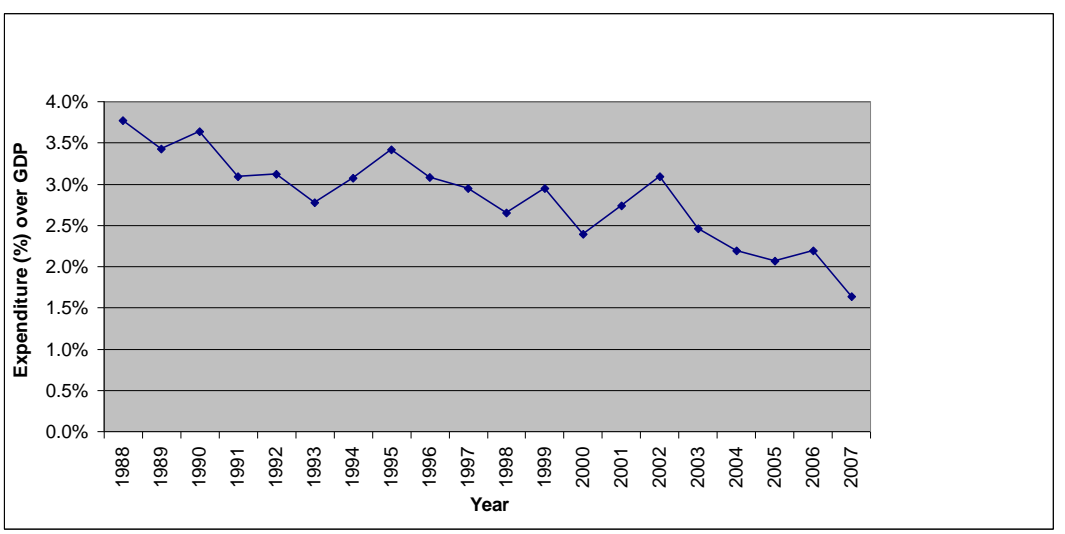

Data Source: Various issues of IISS's The Military Balance 1990-1991 to 2009 and SIPRI's Military Expenditure Database.

Fig. 3 Average Percentage of Defense Expenditures Against the GDP for All 5 Countries

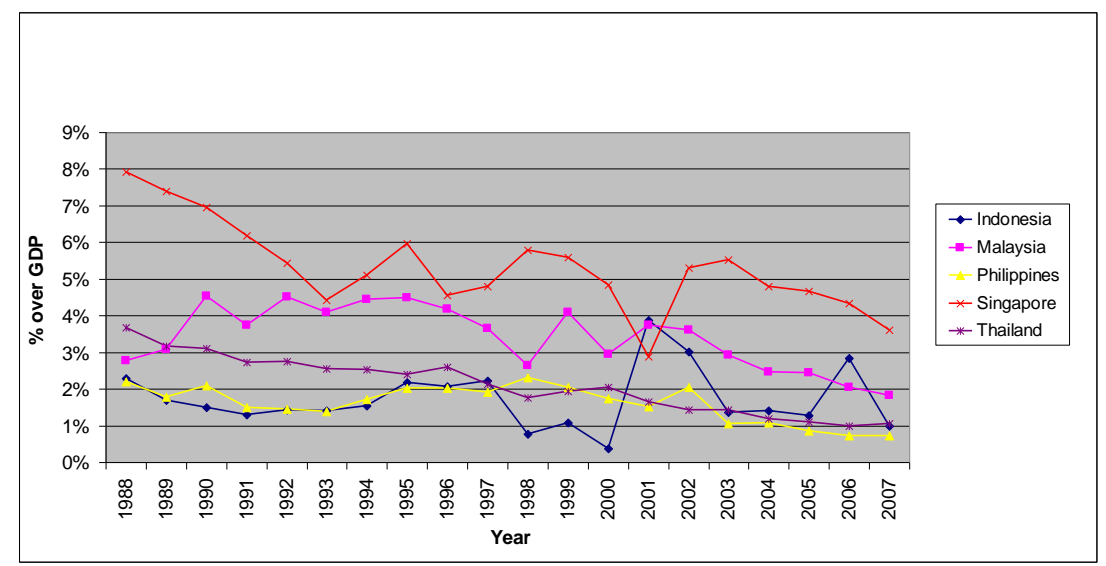

Data Source: Various issues of IISS's The Military Balance 1990-1991 to 2009 and SIPRI's Military Expenditure Database

Fig. 4 Defense Expenditure against Gross Domestic Product for Selected Countries in Southeast Asia

It is also surprising to observe that Singapore, being a city-state and well developed as compared to its larger neighbors, allocated more of its national income towards the development of the country. However, it is only a simple decisive test and more in-depth analysis by other scholars on this particular trend needs to carry out to substantiate it further. When the average of the percentage of defense expenditures compared to the countries' total GDP, there is indeed an indication of a downward trend as shown in Fig. 3 and Fig. 4. A significant downward trend seemed to have begun in 2002. Even though each country may show some fluctuations for their respective defense expenditure as a percentage of GDP, but generally, there is a downward trend since 1988. That means a smaller portion of the yearly budget allocated for defense and the major portion goes towards the development of the country. Comparatively for the period 1988 to 2007, on average, the Philippines 
INTERNATIONAL JOURNAL OF ACADEMIC RESEARCH IN BUSINESS AND SOCIAL SCIENCES

Vol. 9, No. 6, June, 2019, E-ISSN: 2222-6990 @ 2019 HRMARS

had the lowest percentage of defense expenditures at $1.6 \%$ of its GDP, followed by Indonesia at $1.7 \%$, Thailand at 2.1\%, and Malaysia at 3.4\%, and the largest being Singapore at 5.3\%.

\section{Increasing Trend of Actual Amount for Defense Expenditures}

Looking at the actual amount on defense expenditures for each country in this period, generally, it reflects an increasing trend. The main reason for such a trend is that during periods of economic growth, more funds generated or are available for defense expenditures. Despite the decrease of defense expenditures as compared to GDP, the actual amount is in fact increasing. This phenomenon can be explained through the larger national income gained during times of economic growth that have a subsequent effect of an increase in defense expenditures. It observed that Singapore and the Philippines' defense expenditures not affected by the 1997 crisis. Their defense expenditures continue to rise, but the Philippines peaked its defense expenditures in 1999 and 2002. However, since 2003, the defense expenditures levels were similar to prior to 1994. Among the 5 countries studied, Singapore is seen to be the most consistent with its defense expenditure as it continues to rise despite the financial crisis in 1997. A summary of these observations provided in TABLE II. Through this simple analysis, there are some relationships between defense expenditures in times of economic growth and economic depression. In many instances, in times of economic growth, there are more funds available for defense procurements to modernize a country's armed forces. It is evident that this relationship between defense expenditures and economic growth exists. However, Fig. 4 shows the amount of total defense expenditures as compared to their total GDP from 1988 to 2007, which can concluded to be very small.

From the late 1988 to 2007, it is clear that Indonesia, Malaysia, the Philippines, Singapore and Thailand have increased their defense expenditures to improve their military capabilities by acquiring weapon systems suitable for conventional warfare. The capabilities acquired can considered geared for war with other states through the process of 'force modernization'. Besides acquiring new weapon systems, current holdings of equipment refurbished and upgraded to include new technology to prolong the lifespan of this equipment. These acquisitions, refurbishments and upgrades seen to increase the mobility, lethality and reach of this equipment, i.e. developing rapid deployment components. Another assessment is the question of affordability. New weapon systems are very expensive and may take many years to materialize their operational ability as it can observed that many acquisitions on new capabilities can take many years. Generally, in most cases, the acquisitions of new weapon systems are not only to acquire new capabilities, but also to replace antiquated equipment. 
INTERNATIONAL JOURNAL OF ACADEMIC RESEARCH IN BUSINESS AND SOCIAL SCIENCES

Vol. 9, No. 6, June, 2019, E-ISSN: 2222-6990 @ 2019 HRMARS

TABLE II: A Summary of Actual Defense Expenditures Amounts

\begin{tabular}{|c|c|c|c|}
\hline Serial & Country & \multicolumn{2}{|c|}{ Yearly Amount of Defense Expenditures Trends } \\
\hline & & Economic Growth & Economic Depression/Crisis \\
\hline 1 & Indonesia & Increase & Decrease \\
\hline 2 & Malaysia & Increase & Decrease \\
\hline 3 & Philippines & Increase & $\begin{array}{l}\text { Increase but started to decrease in } \\
2003 .\end{array}$ \\
\hline 4 & Singapore & Increase & Increase \\
\hline 5 & Thailand & Increase & Decrease \\
\hline 6 & $\begin{array}{l}\text { Overall for } \\
\text { the five } \\
\text { countries }\end{array}$ & Increase & Decrease \\
\hline
\end{tabular}

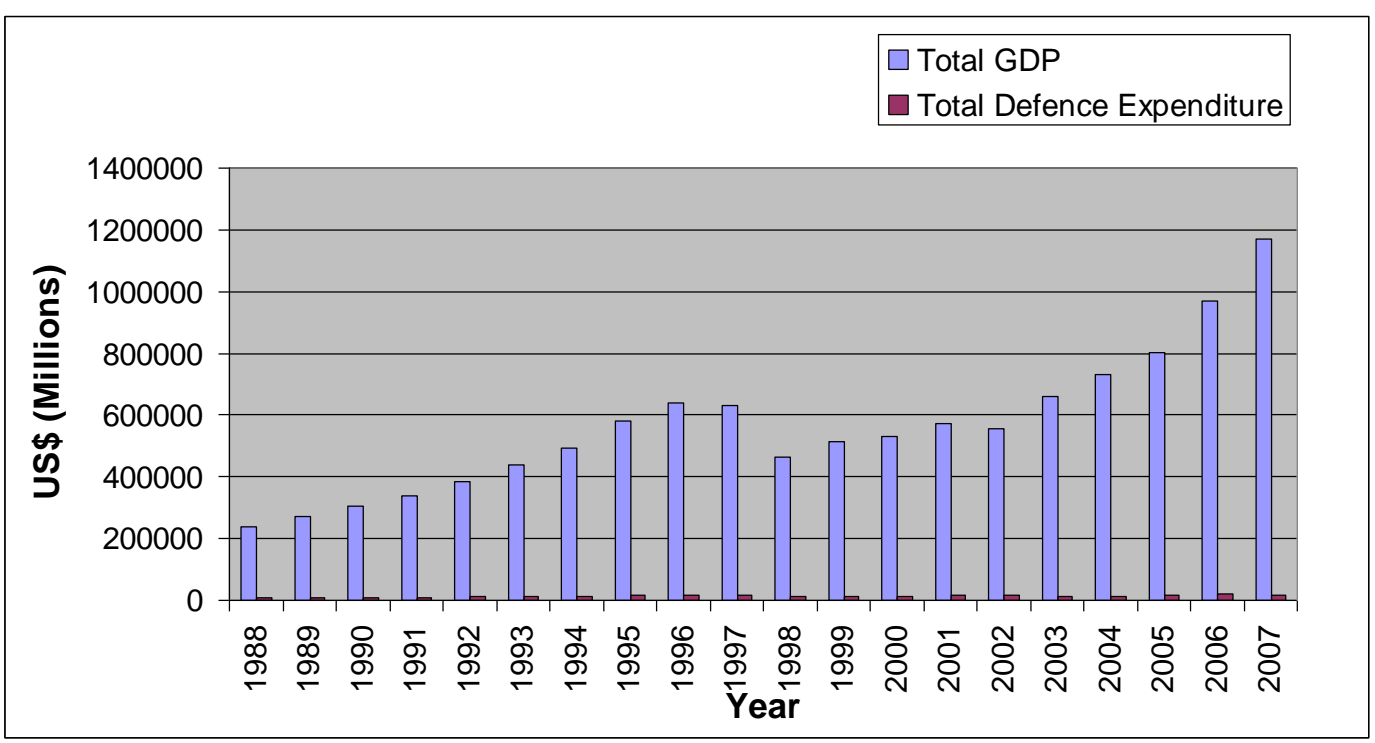

Data Source: Various issues of IISS's The Military Balance 1990-1991 to 2009 and SIPRI's Military Expenditure Database.

Fig. 4: Total Defense Expenditure for 5 Selected Countries With Their Total GDP

Comparatively, Singapore is leading other countries in the region with regard to its defense expenditure as it has been consistently increasing its expenditures even during the 1997 financial crisis. In 2007, Singapore's defense expenditure was USD5.806 billion, followed by Indonesia with USD4.131 billion, Malaysia USD3.409 billion, Thailand USD2.569 billion and the Philippines USD1.034 billion. On the same arguments with the percentage of defense expenditure against the respective country's GDP, Indonesia defense expenditure is much higher than Malaysia's, but Indonesia being the largest and the most populous country, does not commensurate with its defense expenditure unlike Malaysia and Singapore which are smaller in size and less populous. Unlike its counterparts, Malaysia and Singapore were able to spend more on acquiring new modern military equipment due to the larger portion of its GDP allotted for defense. The Philippines economy has the least GDP in 
2007 of USD144 billion as compared to the other 4 countries. However, Indonesia had the largest GDP in 2007 of USD433 billion followed by Thailand with USD245 billion. Malaysia and Singapore, despite the lower GDP of USD187 billion and USD161billion respectively, are much smaller than the other 3 countries, i.e. Indonesia, the Philippines and Thailand. Additionally, its defense expenditure has to account for expenditures for the military operations to contain its internal problems, such as acts of terrorism, the frequent occurrence of natural disasters and its territorial disputes. Thus, it would be correct to deduce that only a small portion of its defense expenditures can allocated for acquiring new weapon systems. Similarly, Thailand and the Philippines faced many problems in acquiring new weapon platforms to modernize their armed forces due to many unresolved internal problems. This is part of the reason where countries in the region have come out with new financing methods to make new military equipment purchases such as 'swaps' with local products, credit and bank loans facilities.

To address the security dilemma concept, many elements reflect the action and reaction of the countries on the modernization of their armed forces through the acquisitions of new military capabilities. Will this situation then lead to increasing tensions between the countries, which could eventually lead to war? It is very unlikely because studies revealed that countries in the region are more concerned with their internal security and securing their land and maritime borders rather than an all-out war as it means that all its efforts of developing the country will come to naught. Additionally, a lot diplomatic efforts to resolve security issues made through their regional association, ASEAN, with numerous confidence building measures being in place. Examples of conflicts resolved peacefully are the Pulau Batu Putih and, the Sipadan and Ligitan maritime overlapping claims were resolved at the International Court of Justice. Otherwise, the relative peace observed in the region since after the Cold War would not have been sustained. However, it is beyond the scope of this study to discuss the regional association efforts to resolve their members' territorial disputes.

Similarly on the arms race concept, this study reveals that the arms acquisitions by countries in the region do not fulfil every aspect of the arms race conditions (Tan, 2004). However, there are elements of it as discussed above. The situation between these 5 countries is more at trying to catch-up with the military capabilities acquired by their neighbors with Singapore taking the lead. The modernization of their respective armed forces is to attain quality equipment that is high performing in line with the development in military technology to acquire national prestige and status. The new capabilities acquired, such as advanced fighter aircrafts, submarines, frigates, radar, tanks and artillery systems, to name a few, also provide force-multipliers that can further enhance the operational capabilities of their armed forces. The transformation of their armed forces capabilities since the end of the Cold War is firstly towards mechanization, followed by informational age technology and finally, towards digitization. There is a trend evolving to integrate the various arms and military equipment systems through joint and combined operations. In other words, this evolving trend is to fully realize the capabilities of the 3 services of the army, navy and air force into one combat force. 
INTERNATIONAL JOURNAL OF ACADEMIC RESEARCH IN BUSINESS AND SOCIAL SCIENCES

Vol. 9, No. 6, June, 2019, E-ISSN: 2222-6990 @ 2019 HRMARS

\section{Factors Affecting the Defense Expenditures}

Military Technological Advancements

Countries in the region, particularly Singapore have taken into account the US experience not only from the First Gulf War (Tan, 2004) but also in the Second Gulf War. The new technology deals with new information, sensing, precision attack, stealth and aerial warfare technologies employed in the Gulf that show how wars will be fought in the future (Tan, 2004). The countries in the region in the 1990s were moving towards mechanization. The early 20th Century saw the impact on the rapid development in information technology and the later part of the first decade of the 20th Century saw the move towards digitization where new capabilities acquired are capable of dealing with complex war situations as evident on the military technology development in the wars of Iraq and Afghanistan. Adamsky stated that: "...the classical patterns of advancement along fronts with discernible lines and rear areas have disappeared; the number of platforms have become far less important than networks and communications; operations aim at defined effects rather than attrition of enemy forces or occupation of territory; instead of massive forces, precise fire is maneuvered; the sensor to shooter loops have been shortened considerably; the role of stand-off and air power capabilities have increased at the expense of heavy ground formations; a far smaller, lighter and more mobile force can operate on a greater range with higher precision and lethality" (Adamsky, 2008). Singapore is seen to be able to achieve a 'digitised force' due to its consistency in procuring new weapon platforms, efficiency and systematic approach towards modernizing its armed forces. However, there are instances where countries were unable to procure advanced military equipment and opt for the 'second best' option instead when the country is faced with limited funds for procuring the 'nextgeneration' military equipment, such as Thailand's purchase of the Gripen fighter aircrafts. In other words, purchasing 'second-hand' or used military equipment can help acquire the capabilities that are perceived to be able to counter the new acquisitions made by their neighbors.

There is a saying in the military that in times of peace, the military prepares for war. Due to the ever changing in the enhancement of military technology and the complexities of war, these nations in the Southeast Asian region are in part preparing themselves militarily for such a contingency. It may not be a war between the nations here, but to be capable of dealing with the uncertainties and the development of non-military threats that exist in the region.

\section{Quality, Prestige and Force-Multipliers}

Security analysts are suggesting that the modernization of the countries in Southeast Asia is to possess a certain degree of prestige so as not to 'lose face' with its neighbors (Huxley, 2000; Tan, 2004). The possession and displaying of sophisticated military equipment amongst the countries in the region are also a matter of national prestige (Huxley, 2008). In other words, it is a competition between them to keep-up with the military developments of their neighbors. In relation to the prestige factor, the situation also relates to the quality of the capabilities acquired where the Western technology seen to be much more superior as compared to their Eastern European counterpart. Besides that, the arms acquired are from many Eastern European countries, mainly from Russia. Overall, most of the military equipment purchased is from the Western countries. For instance, Malaysia purchased the Mig 29s and Su-30MKM from Russia, but other major purchases include the F-18s from the US, frigates from the UK and submarines from France. 
This diversification of procuring arms from different countries reduces the advantage of any major powers in times of political animosity that may exist between the two countries in the future. An example would be the US embargo on Indonesia that previously thwarted spares for US equipment previously acquired for the maintenance and upkeep for Indonesia's US related military equipment (Tan, 2004). The embargo could also explain the lack of parts for maintenance of its military aircrafts that were involved in many fatal crashes. Another aspect of quality is the upgrading and refurbishments of current holdings of military equipment with new technology (Bhonsle, 2008) to further enhance their life span and capabilities. Major purchases, for instance, AEW aircrafts, air-toair refuelling aircrafts, submarines and radars are examples of the force-multiplier effects that can further enhance their armed forces capabilities and further add to its national prestige.

\section{Arms Race or Maintaining the Status Quo}

The security dilemma of one country's increase in its arms purchases could also lead to the increase of another and thus may lead towards an arms race phenomenon. The arms race between these 5 countries is more of a situation of keeping-up with their neighbors with Singapore being the 'yardstick'. For example, the acquisitions of new submarines by Malaysia and Singapore, has made Thailand and Indonesia to acquire the same so as to be at par with their counterparts. The Philippines is unable to do so yet due to its country's financial predicament. Currently, it is still focusing on neutralizing its internal threats and its modernization plan for its armed forces is delayed (Hartfiel and Job, 2007). The arms build-up between these countries is from 'within' where their armed forces are not only capable of assisting the civilian authorities with the internal threats, but also its armed forces are capable of defending the country from any external threat.

Buzan stated that if defense expenditure of a country is expressed as a percentage of its national income, in this case, its GDP, then the trend indicates a constant or declining percentage of its national income and the country is maintaining the military status quo, which means that the country's defense spending on purchasing arms and equipment is to retain current capabilities by replacing obsolete or antiquated weapons or equipment with new modern ones [4]. However, Buzan also stated that the usage of defense expenditure as a percentage of the country's national income has to be used with caution because different growth rates can have a large impact on the interpretation of the figures [4]. This is actually quite true because the 5 countries studied here do have differing national income figures and the amount is quite significant as can be seen from the amount of GDP achieved by these countries in the last two decades. Additionally, even though the overall picture reflects a downward movement of defense expenditures as a percentage of GDP, the actual amount for defense expenditures for countries in the region is actually on the rise. In other words, even though defense expenditure as a percentage of GDP is generally seen to be decreasing, the actual amount for defense expenditure is on the rise because of the larger GDP achieved as previously recorded, particularly during times of economic robustness. With regards to maintaining a military status quo, this study duly reflects that it is not so as these countries are striving to acquire a reasonable degree of a modern conventional force with highly sophisticated weaponry. This act of modernizing their armed forces with technologically advanced weapon systems is in tandem with the developments of modern warfare capabilities as evident in the wars in Iraq and Afghanistan. The 
INTERNATIONAL JOURNAL OF ACADEMIC RESEARCH IN BUSINESS AND SOCIAL SCIENCES Vol. 9, No. 6, June, 2019, E-ISSN: 2222-6990 @ 2019 HRMARS

countries in the region are generally moving away from counter-insurgency operations towards advanced war fighting capabilities (Gething and Caffrey, 2008).

It is said that among military practitioners, in times of peace, a country's armed forces should be prepared for war so as to ensure the survival and safety of the country. Countries in the region generally acquire and maintain technological superiority to ensure that if war or any major conflict occurs in the region, they are able to defend themselves and achieve victory. Among the countries studied here, Singapore is regarded to be well ahead of its neighbors and it wants to ensure that it continues to have the edge over any opponents in the region if a major conflict happens (Huxley, 2008). This could be the paranoia by Singapore of its bigger Muslim neighbors of Malaysia and Indonesia. Indonesia's Konfrontasi with Malaysia in the mid-1960s, and being the smallest state which is sandwiched by these two countries do provide some basis for Singapore to behave as such. Additionally, any instability in these two countries may overflow into Singapore and could affect its stability as well. Thus, the concepts of military technology and war do have some credence for these countries in the region to modernize their armed forces with technologically advanced weapon systems so as firstly to contain any internal threats and secondly, to assure its sovereignty and integrity.

\section{Conclusion}

The reasons why Indonesia, Malaysia, the Philippines, Singapore and Thailand continue to increase their defense expenditures even when there is relative peace in the region after the Cold-War are affected by numerous factors. The modernization process for these countries' armed forces is to acquire advanced military technology to replace outdated weapon systems and military equipment so as to transform their armed forces into a credible, modern conventional force from a previous counter-insurgency force. The modernization process is also in part to keep-up with the military capabilities acquired by their neighbors and to attain the quality, prestige and force-multipliers effect for the sake of national status. In terms of financial affordability of countries in the Southeast Asian region in general, certain creative measures are taken to acquire the necessary 'new' military equipment besides upgrading and refurbishments of old weapon systems and equipment.

The modernization of the selected countries' armed forces in this study began with the withdrawal of major powers in the 1960s, 1970s, 1980s and the security uncertainties that faced the region after the Cold War. Among the uncertainties were the concern over the withdrawal of major powers of the US and Soviet Russia, and the growth of China's military and economic prowess and the circumstances over the issues developing in the Spratly islands in the South China Sea. The vacuum left by the major powers after the Cold War was the beginning of the armed forces modernization process for the countries studied here. This resulted these countries to realize that there is no guarantee for major powers to provide any assistance to these countries from any potential aggressor. Thus, these countries started to develop their armed forces for their own defense and security. In other words, it is a self-help system by transforming their armed forces into a conventional force from a counter-insurgency force to fulfil this requirement.

In summary, this study has clearly indicated that there are many factors that relate to the force modernisation and arms purchases in the region. It is a complex situation to fully understand all the reasons behind the defense expenditures trends for these countries in modernizing their armed 
forces. Among the reasons that can be concluded here are the desires by these countries to acquire the 'next-generation' capabilities which involve the advancement in military technology so far achieved in this new century. By acquiring and displaying this technologically advanced military equipment, it gives the countries a sense of quality and prestige attained. Thus, the arms build-up in these countries is not actually an arms race, but rather a situation of commensuration with their neighbors' force modernization. There are also new evolving trends of purchasing humanitarian and disaster relief equipment for the armed forces. This situation only shows the ever-changing security requirements and uncertainties in the region where non-traditional threats are emerging as well as involving environmental issues.

\section{Acknowledgement}

My heartfelt gratitude and appreciation to all my co-researchers for their tireless assistance and comments in the successful completion of this study. In addition, to the Dean, Faculty of Defense Studies and Management; and the Vice Chancellor, National Defense University of Malaysia itself for their insistence towards research contributions for the university.

\section{Corresponding Author}

Amirudin Sulaiman, National Defense University of Malaysia, Kem Perdana Sungai Besi, 57000 Kuala Lumpur, Malaysia, Email: amirudinsul@gmail.com

\section{References}

Adamsky, D. P. (2008). Through the Looking Glass: The Soviet Military-Technical Revolution and the American Revolution in Military Affairs. The Journal of Strategic Studies, Vol.31. No.2. April: 258.

Bhonsle, R. K., Brig (Retd). (2008). Military Modernisation in the Asia Pacific: Sowing the Seeds of An Arms Race. 22nd Asia Pacific Roundtable Papers. Institute of Strategic and International Studies (ISIS) Malaysia. 3-5 June: 6.

Buzan, B. (1987). An Introduction to Strategic Studies: Military Technology and International Relations. International Institute for Strategic Studies. Macmillan: 81.

Chin, K. W. (ed). (1987). Defense Spending in Southeast Asia, Issues in Southeast Asian Security. Institute of Southeast Asian Studies. Singapore: 1-2.

Hartfiel, R. \& Job, B. L. (2007). Raising the risks of war: defense spending trends and competitive arms processes in East Asia. The Pacific Review. Routledge: 6.

Hartley, K. \& Sandler, T. (ed). (1990). The Economics of Defense Spending, An International Survey. Routledge. London and New York: 1.

Huxley, T. (2000). Defending the Lion City, The Armed Forces of Singapore. Allen \& Unwin. Australia: 250.

Huxley, T. (2008). Defense Procurement in Southeast Asia. Paper presented at the 5th workshop of the Inter-Parliamentary Forum on Security Sector Governance (IPF-SSG) in Southeast Asia, Phnom Penh. 12-13 October: 4-5.

Gething, M. J. \& Caffrey, C. (2008). Keeping balance: Southeast Asian air forces face varying challenges. Jane's International Defense Review. Volume 41. February: 49. 
INTERNATIONAL JOURNAL OF ACADEMIC RESEARCH IN BUSINESS AND SOCIAL SCIENCES

Vol. 9, No. 6, June, 2019, E-ISSN: 2222-6990 (C) 2019 HRMARS

IISS The Military Balance (2005-2006): 11-12.

MIDMC, (2007), Readings in Defense Resources Management, Pearson Custom Publishing, Boston, United States of America: 3-5.

Tan, A. (2004). Force Modernisation Trends in Southeast Asia, Working Paper No. 59. Institute of Defense and Strategic Studies. Singapore. January: 5-6; 15; 33.

Whynes, D. K. (1979). The Economics of Third World Military Expenditure. The MacMillan Press Ltd: 4-6. 